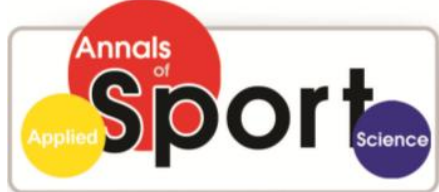

www.aassjournal.com

e-ISSN : $2322-4479$

p-ISSN : 2476-4981

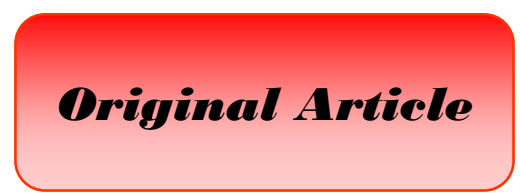

Received: $27 / 12 / 2014$

Accepted: 22/05/2015

\title{
The Effect of Brand Extension Strategy on Its Image: The Case of Majid Brand
}

\section{Fatemeh Abdavi*, Zahra Shiralizadeh}

Department of Sport Management, Faculty of Physical Education and Sport Science, University of Tabriz, Tabriz, Iran.

\begin{abstract}
This descriptive-correlational study examined the effect of brand extension on current image in the scope of Tabriz Majid products in the city of Tabriz. The study population comprised consumers of Majid products and fans of Tractorsazi, and the sample size was 380 persons. A simple random sampling method and an infinite population formula were used as well as a fiveoption Likert questionnaire. Its reliability was measured at 0.71 by Cronbach's alpha coefficient. The Spearman ranking correlation coefficient test and structural equations model, available on SPSS and LISREL software packages, were used to analyze the data. The most important results of the study indicate that extension attitude affects brand image. Furthermore, initial brand communications and perceived fitness between the new product and other products (category fitness) or brand image (image fitness) can improve and affect consumer attitude.
\end{abstract}

Key Words: Brand Extension, Brand Image, Perceived Fitness, Extension Attitude, Consumer Modernism.

Corresponding Author:

Fatemeh Abdavi

E-mail: fatemehabdavi@yahoo.com 


\section{INTRODUCTION}

Branding and brand management are popular in the world of marketing. A brand is a mechanism through which buyer and seller are connected with each other for a long time; brand plays an important role in making that relationship. According to mass producers who attempt to produce a product category or the same service, customers focus on brand when making purchasing decisions. Making a powerful brand in the market is the aim of many organizations (1). A brand is a name, term, sign, logo, or design, or a combination of them that is used to identify products or services of a seller or a group of sellers and distinguishes the products or services from competitors' products and services (2). Buyers face questions when making decisions in the purchase process, and product variety gives customers many choices. Firms have found that the cost of attracting new customers is five times more than that of keeping current customers (3). Main concerns of companies that require the clearest marketers' professional skill in today's competitive markets are keeping customers, developing market share, and, in fact, making, keeping, and promoting a brand (4). Introducing a new brand to the market assigns a considerable price to itself. Accordingly, the ability of a brand to simplify customers' decision making, reduce risk, and define their expectations is invaluable (5). Therefore, brand extension strategy and consumer choice expansion to various products have become the most popular ways to promote business growth. Brand extension is the use of a brand registered in one product category in another category of products (69). It causes a product to quickly gain a reputation and garner acceptance among consumers. Advertising these products and services does not require high expenditures (10). Marketers believe that, in most cases, brands are evaluated as highly desirable by customers because customers transfer the positive features and emotions of the main brand they have in mind to extended products (11, 12). Therefore, in new markets, companies try to use one of their existing brands (in the form of brand extension) rather than making a new one (13). In today's competitive markets a business must keep its customers and increase their purchases, because keeping existing customers is less costly than attracting new ones. This has caused companies to seek strategies that not only reduce the costs of keeping current customers, but also increase the number of customer purchases. One of these strategies is brand extension. The current study investigated the primary image of a brand as the main variable and as one of class and image fitness and extension trend and consumer modernism as other variables. Studies have demonstrated a correlation between class fitness and consumer attitude toward brand extension as well as between image fitness and consumer attitude. The present study achieved results similar to those in the mentioned studies. Studies have also shown that brand image has a significant effect on consumer attitude toward brand extension (14). In their study, Martinez and Pina showed that brand extension strategy is effective on brand image after the extension (6). According to Hirschman in 1984, the concept of modernism as a personality feature, the inner or inherent desire of a person to seek information, reflects new stimulus or experience. Hart et al. stated in 1977 that consumer modernism is often considered a personality feature that reflects a willingness to change (15).

Most Iranian companies seem to have no exact strategy for brand extension or increasing their market share. A poor scientific and comprehensive attitude that can show the whole strategy of brand extension for companies has caused the implementation of this strategy in practice not only to have no considerable income or success for them, but 
also to sometimes damage sales and the products' positions with the main brand. The process by which consumer attitude becomes brand extension to its image must be understood. The importance of the sports industry in the current era, especially the popular and attractive sport of football and the impressive successes of sport brands, has drawn attention to this industry; yet to date, no study has been conducted on the field of sports and sport brands in Iran. Therefore, the current study purposed to examine the effect of brand extension strategy on its image focusing on the effect of Majid brand extension on its image in Tabriz because of Majid's financial support of national football, volleyball, and wrestling teams and the many fans it has in the country, especially in the city of Tabriz. Questions considered by this study were, (a) whether brand extension strategy would be successful in a market and lead to an increase in purchases of a new product that uses an existing brand, and, more importantly, (b) what effect brand extension attitude would have on its image after extension. The authors have attempted to prevent the loss of an organization's time and money, the failure of brand extension projects, and the negative impacts on the mother brand image by clarifying the factors affecting brand image due to its extension.

Study Conceptual Model. A process by which brand extension affects its image is expressed by the following model:

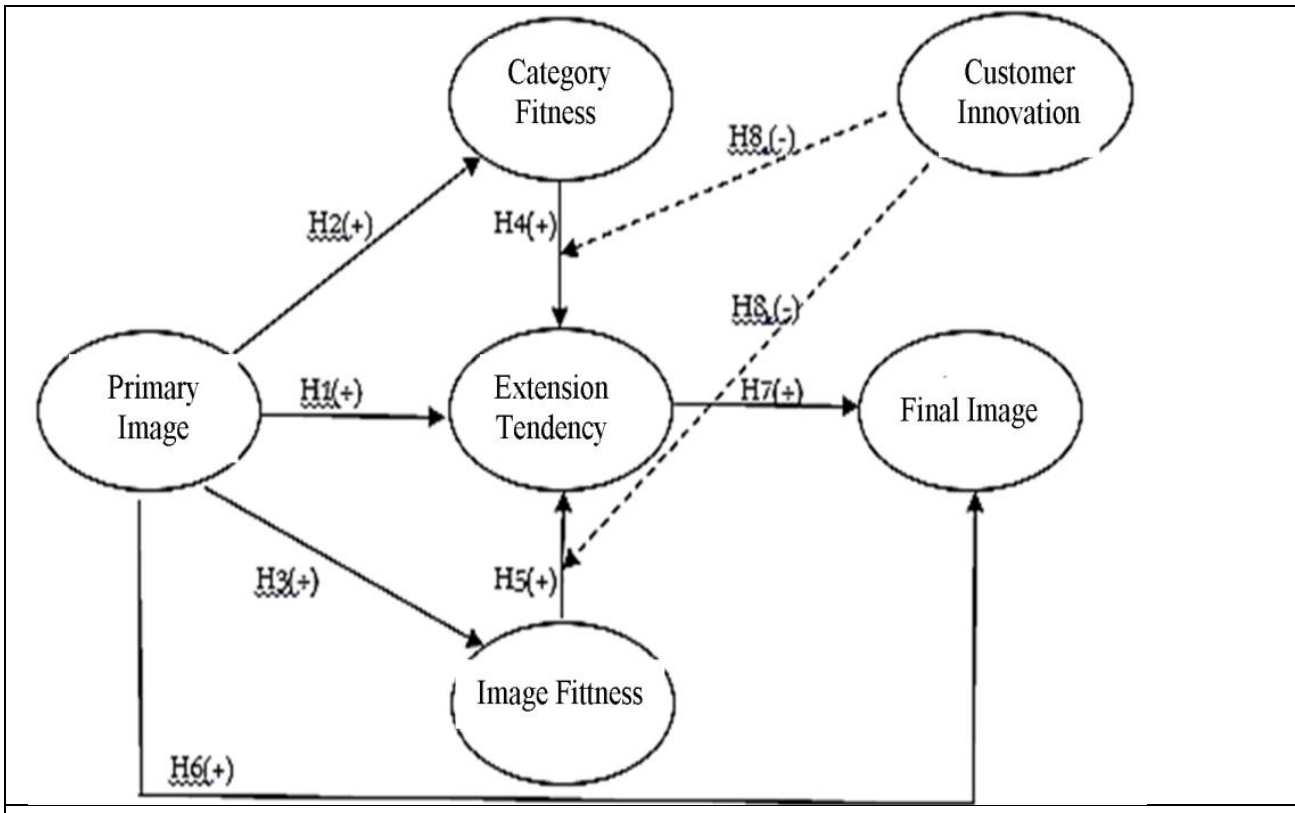

Figure 1. The conceptual model to examine the effect of brand extension on its image (6).

\section{MATERIALS AND METHODS}

This descriptive-survey collected data through a standard questionnaire based on the 5-point Likert scale with answers ranging from strongly agree to strongly disagree.

Participants. The study population was all Tractorsazi Club Fans and Majid product consumers in the city of Tabriz, Iran. Since the population size was unlimited, the simple random sampling method and the sampling formula for infinite population with allowed error (0.05) were used. The statistical sample consisted of 400 consumers and fans that were distributed in sport stores and among the fans and customers of Majid brand.

Statistical Analysis. In studies that examine a particular model of a relationship between variables, structural equation model 
(SEM) analysis is used (Homan, 2008). Therefore, to examine the study hypotheses and generalize the results of the studied sample to the population and to explain and measure the relationship between factors, the statistical methods of correlation and structural equation model.

\section{RESULTS}

Descriptive Findings. Among the 380 respondents, men were assigned the highest percentage with $90.5 \%$. The age distribution of respondents was $73.5 \%$ ranged 20 to 40 years in age. Most respondents did not have a high school diploma (29.7\%), and the average monthly expenditure of $40.3 \%$ of respondents was less than \$200 US.

Examining the general model and hypotheses using the structural equation model. Figures 2 and 3 show the final results of the structural equation model in two standard cases and significant numbers. As seen, standard coefficients $(\beta)$ and the proposed causal relationship between study variables are reflected in these figures. Fitness indices indicate that the model is in relatively good condition. Because the chi-square ratio to degree of freedom equaled 2.46, which is less than the allowed value of 3 , and the RMSEA value equaled 0.015 , which is also less than the allowed value of 0.08 , little modification was needed. The GFI value in this model was 0.94, and the AGFI value equaled 0.92, which indicates a good condition. Based on the model, all significant numbers related to the model parameters were larger than 1.96 and significant; as a result, all study hypotheses (1 to 7) are confirmed.

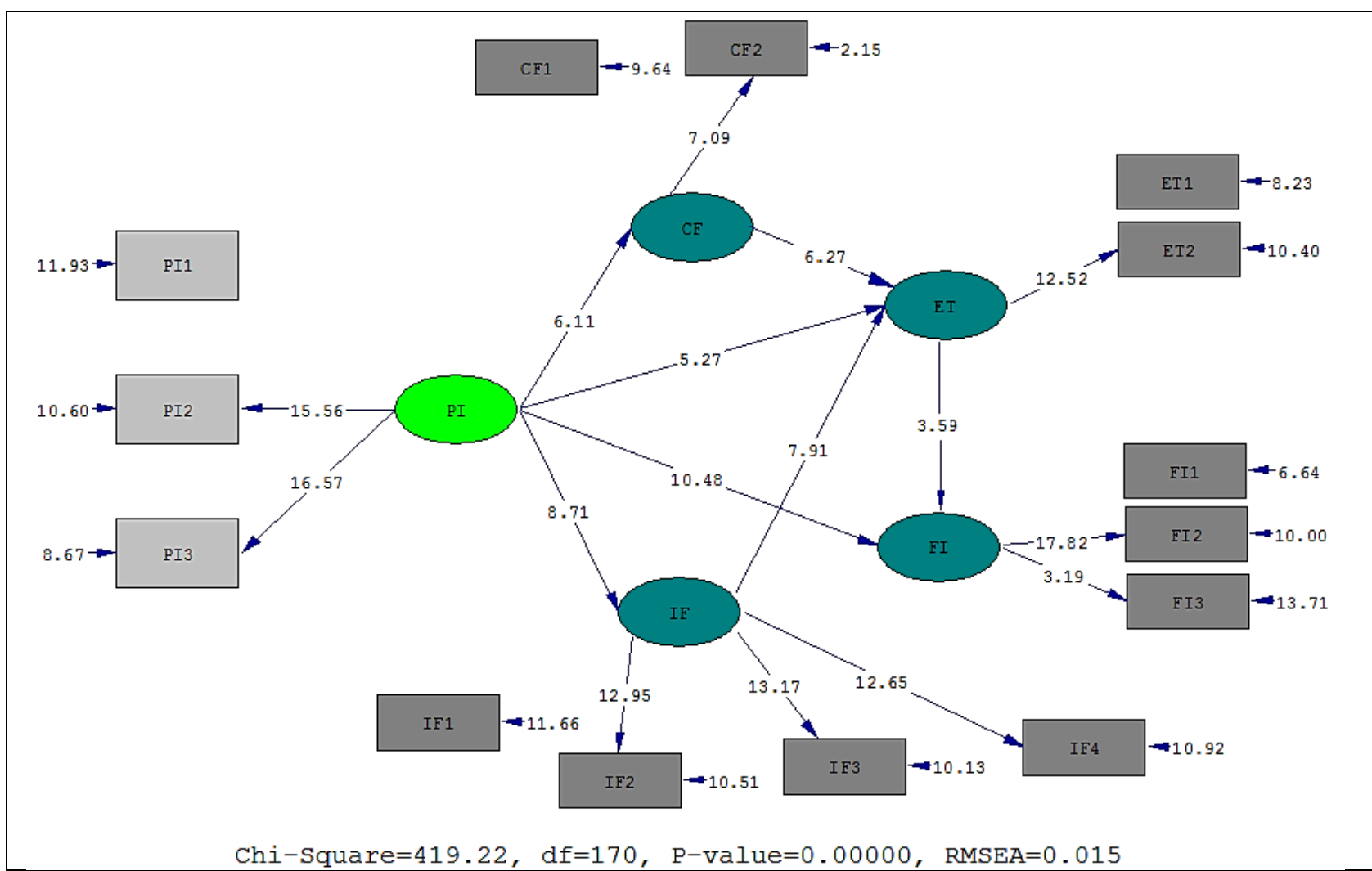

Figure 3. Structural equation model of standard numbers. PI: Primary Image, FI: Final Image, CI: Customer Innovation, CF: Category Fitness, IF: Image Fitness, ET: Extension Tendency. 


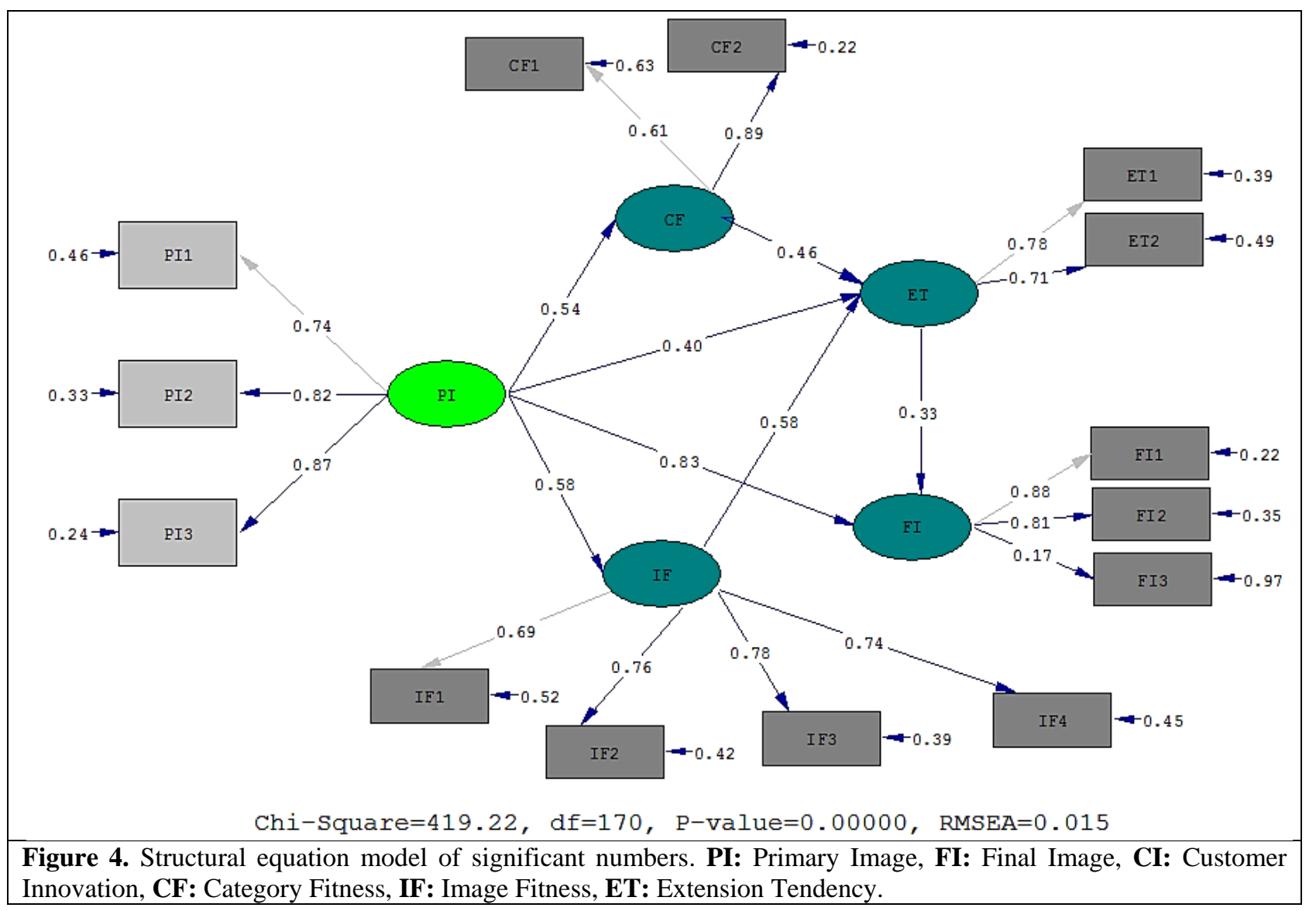

The adjusted structural equation model (MSEM) was used to test H8. For this purpose, the $\mathrm{R}^{2}$ test was used to investigate whether the variable modernism was an adjusting variable. After adding an interactive sentence to the regression equation, the $\mathrm{F}$ significance for the trend dependent variable was less than 0.05; therefore, the assumption of equality of the determination coefficients was not confirmed. In other words, after adding the interactive sentence, the correlation coefficient and the coefficient of determination were changed. This shows that the modernism variable can be considered an adjusting variable of the relationship between category fitness and image fitness with extension trend. To calculate the interactive sentence, two variables should be multiplied; to prevent linearity in calculating the regression in this study, the standard values of variables (ZSCORES) were used. These standard values were first calculated using SPSS and LISREL software and path analysis; then the relationship between the interactive sentence and the dependent variable was investigated. As seen in the figure below, the absolute value for a significant number for the interactive sentence (modernism and category fitness) was higher and more significant than 1.96 (2.80). Furthermore, it was negative. Thus, it can be concluded that modernism reversely adjusts the relationship between category fitness and extension, and H8 (a) is confirmed: 


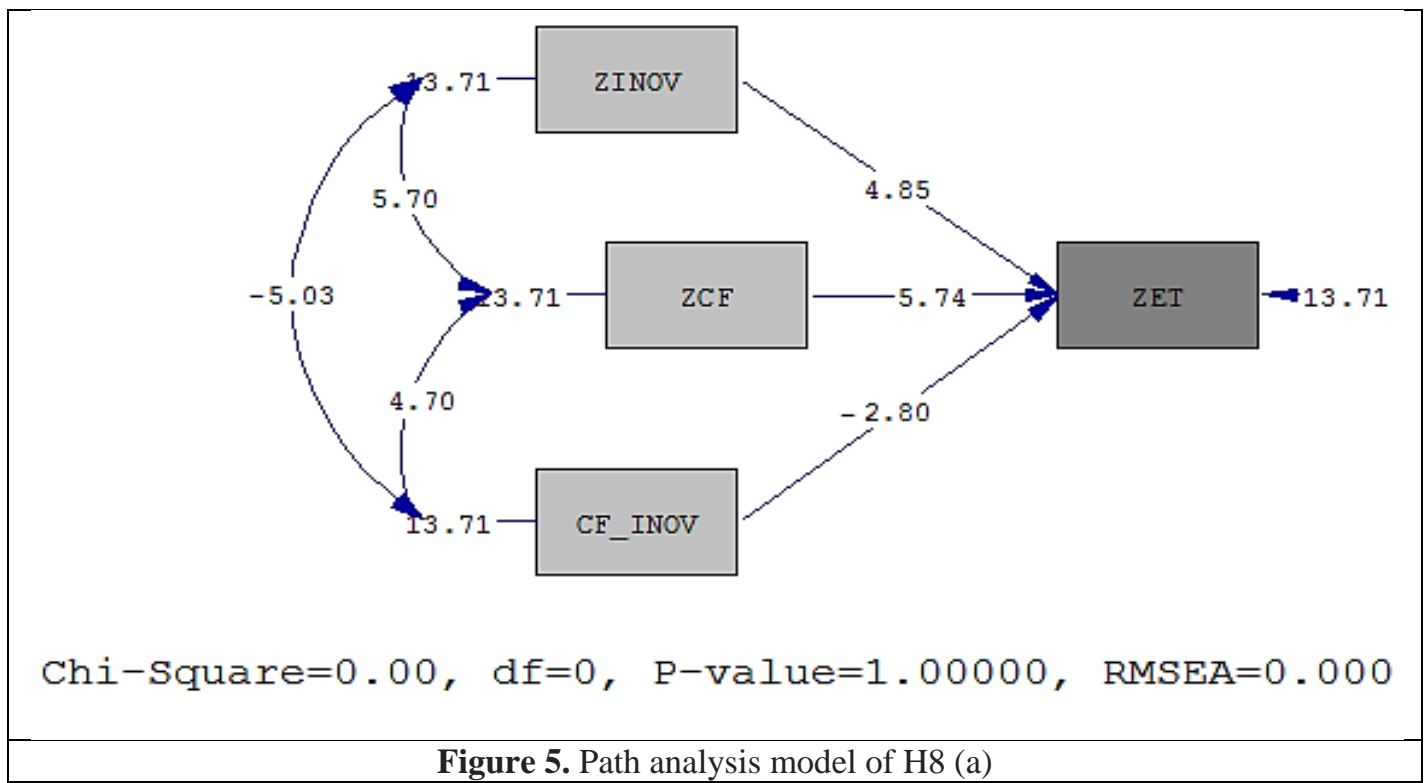

The absolute value of a significant number for an interactive sentence (modernism and image fitness) was larger and more significant than 1.96 (5.71), and it

was negative; therefore, it can be concluded that modernism reversely adjusts the relationship between image fitness and extension tendency, and H8 (b) is confirmed:

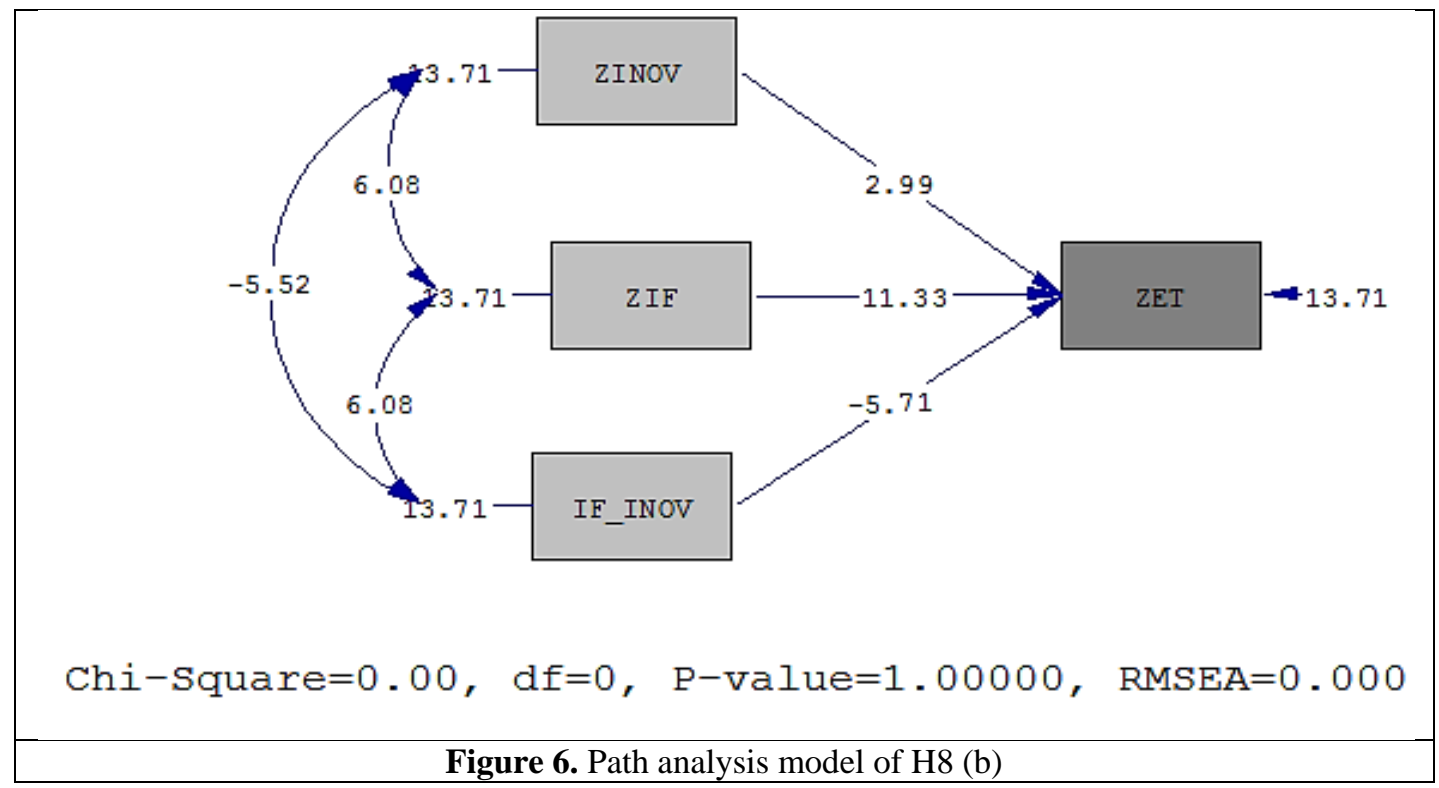

\section{DISCUSSION AND CONCLUSION}

Today, marketing specialists understand the importance of brand and its role in the success of an organization's marketing scope. One issue related to brand that has attracted the attention of many marketing professionals is extension. Brand extension strategy increases the chances of new goods to succeed (16). Therefore, to examine the results of brand extension, a proper 
understanding of the main brand image is necessary, because image is an effective factor in this field.

In this study, the effect of brand extension variables on its image was investigated. The results show that a brand's initial image, perceived fitness, extension attitude, and consumer modernism are effective on its final image; among these variables, initial image had the highest effect on a brand's final image. According to the structural model coefficient, the effect of initial image on a brand's final image equals 0.83 ; if customers have a good brand image in mind, the brand extension will be more successful in the marketplace. Based on confirmed hypotheses $1,2,3,6$, and 7 , it can be concluded that in Iran, society's initial image of a brand has a high effect on extension attitude, perceived category fitness, perceived image fitness, and the brand's final image. Therefore, the need for proper planning to enhance the positive effect of this variable on brand extension is necessary. The results of these hypotheses are consistent with the results of studies conducted by Vazifehdust and Hariri, 2012; Dehghani Soltani, et al., 2013; Völckner and Sattler, 2006; van Riel, Lemmink, and Ouwersloot, 2001; and Serrao and Botelho, 2008 (14, 17-20). Furthermore, studies by Vazifehdust and Hariri, 2012, Aaker and Keller, 1990, Bhat and Reddy, 2001, and Klink and Smith, 2001; have proven that category fitness has a direct effect on consumers' attitudes of brand extension (11, $12,19,21)$. The findings of the present study are consistent with those of studies by $\mathrm{MaOz}$ and Tybout, 2002; and Jung and Tey, 2007; who believed that successful extension is partly inconsistent with the main brand (8, 22 ). Since the role of a brand's initial image was found by all studies to be effective on its final image and the attitude was seen as very effective on extension, it is recommended that prior to extension, companies be sure of their brand's image in the minds of consumers. If the brand's current image is not good, it must be changed; only if the current brand image is good should the brand be extended.

\section{APPLICABLE REMARKS}

- The results of the present study indicate that producers should know that their products' original image is essential for more successful development and extension. They should be certain of their products' image when attempting to extend its initial brand image in the minds of consumers and customers. If their image is not good in the market, managers should boost their initial image and then extend.

- Industries and companies in the market should consider product fitness when intending to extend, because the perceived fitness of the type of category and image are considered powerful determinants in consumers' attitudes toward extension. Therefore, companies should consider that a higher level of fitness between the main product of brand and new products due to brand development can have a more positive effect on the success of the extension process.

- Considering that attitude toward a brand will play a major role in increasing brand extension success, it is recommended that companies make, keep, and promote the attitude of consumers when trying to extend. 


\section{REFFRENCES}

1. Keller KL. Conceptualizing, Measuring, and Managing Customer-Based Brand Equity. Journal of Marketing. 1993;57(1):1-22.

2. de Chernatony L, Dall'Olmo Riley F. Defining A "Brand": Beyond The Literature With Experts' Interpretations. Journal of Marketing Management. 1998;14(5):417-43.

3. Amirshahi M, Yazdani H, Parsa S. The Influence of Knowledge about Product Category and Difference in the Quality among Brands in Acceptance of Brand Extension. Strategic Management Thought. 2012;6(1):107-32 [Article in Farsi].

4. Kotler P, Keller KL. Marketing Management. 15th ed: Pearson Education; 2014. 832 p.

5. Keller KL. Strategic brand management: building, measuring, and managing brand equity. 2nd ed: Prentice Hall; 2003. 788 p.

6. Martínez Salinas E, Pina Pérez JM. Modeling the brand extensions' influence on brand image. Journal of Business Research. 2009;62(1):50-60.

7. Swaminathan V. Sequential brand extensions and brand choice behavior. Journal of Business Research. 2003;56(6):431-42.

8. Jung K, Tey L. Extending the Fit Hypothesis in Brand Extensions: Effects of Situational Involvement, Consumer Innovativeness and Extension Incongruity on Evaluation of Brand Extensions. KDI School of Pub Policy \& Management Paper [Internet]. 2007 2014. Available from: http://ssrn.com/abstract=994764.

9. Yeo J, Park J. Effects of Parent-Extension Similarity and Self Regulatory Focus on Evaluations of Brand Extensions. Journal of Consumer Psychology. 2006;16(3):272-82.

10. Ambler T, Styles C. Brand development versus new product development: towards a process model of extension decisions. Marketing Intelligence \& Planning. 1996;14(7):10-9.

11. Aaker DA, Keller KL. Consumer Evaluations of Brand Extensions. Journal of Marketing. 1990;54(1):27-41.

12. Bhat S, Reddy SK. The impact of parent brand attribute associations and affect on brand extension evaluation. Journal of Business Research. 2001;53(3):111-22.

13. Yorkston E, Nunes J, Matta S. The Role of Implicit Theories in Brand Extendibility. Marshall School of Business Working Paper [Internet]. 2007 2014. Available from: http://ssrn.com/abstract=995247.

14. Serrao P, Botelho D. Effect of Brand Extension on Brand Image: A Study in the Brazilian Context. Latin American Advances in Consumer Research. 2008;2:22-7.

15. Park JE, Yu J, Zhou JX. Consumer innovativeness and shopping styles. Journal of Consumer Marketing. 2010;27(5):437-46.

16. Martínez E, Montaner T, Pina JM. Brand extension feedback: The role of advertising. Journal of Business Research. 2009;62(3):305-13.

17. van Riel ACR, Lemmink J, Ouwersloot H. Consumer Evaluations of Service Brand Extensions. Journal of Service Research. 2001;3(3):220-31.

18. Völckner F, Sattler H. Drivers of Brand Extension Success. Journal of Marketing. 2006;70(2):18-34.

19. Vazifehdust H, Hariri M. Effect of Brand Extension Strategy on Brand Image on FMCG and Services Sectors. Jounal of Marketing Management. 2012;7(15):41-66 [Article in Farsi].

20. Dehghani Soltani M, Mohammadi E, Purashraf Y-a, Sayehmiri K. A Survey of Effective Factors on Evaluating Consumers, Attitude towards Brand Extension. Iranian Business Management. 2013;5(1):85-104 [Article in Farsi].

21. Klink RR, Smith DC. Threats to the External Validity of Brand Extension Research. Journal of Marketing Research. 2001;38(3):326-35.

22. Maoz E, Tybout AM. The moderating role of involvement and differentiation in the evaluation of brand extensions. Journal of Consumer psychology. 2002;12(2):119-31. 
تازههاى علوم كاربردى ورزش

مقاله اصيل

دوره سوم، شماره جهارم

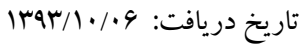

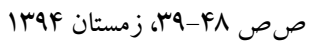

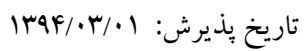

\section{تأثير استراتزى تعميرم برند بر تصوير آن: مورد مطالعه برند مجيد}

\section{'فاطمه عبدوى *' زّهرا شير عليز اده}

ا. استاديار كروه مديريت ورزشى، دانشكده تربيت بدنى و علوم ورزشى، دانشگاه تبريز، تبريز، ايران. r. كارشناس ارشد مديريت ورزشى، دانشكده تربيت بدنى و علوم ورزشى، دانشگاه تبريز، تبريز، ايران.

جكيده

هدف اين مقاله بررسى تأثير تعميه برند بر تصوير آن در حوزمى محصولات مجيد در شهر تبريز بود. از اين رو جَّونكى تأثير تعميم برند بر

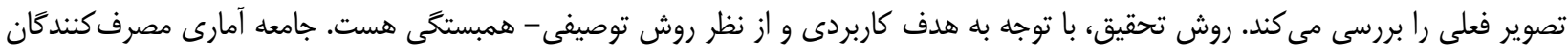

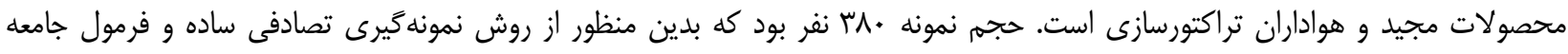

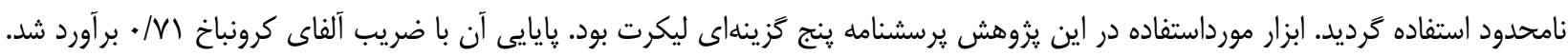

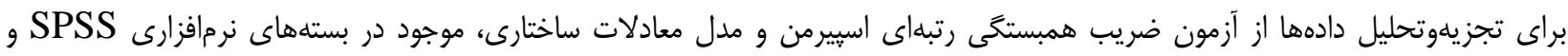

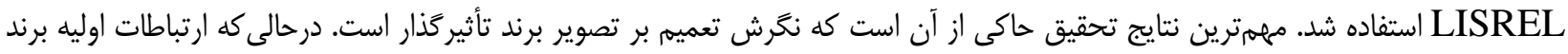
و تناسب ادراكشده ميان محصول جديد و ساير محصولات (تناسب طبقه) يا تصوير برند (تناسب تصوير) مىتوانند نكرش مصرفكننده را بهبود بخشند و اثر كذار باشند. وازَّان كليدى: تعميم برند، تصوير برند، تناسب ادراك شده، نحَرش به تعميه، نوكَرايى مصرفكننده. 
